\title{
DEGRADASI PESTISIDA DIAZINON DENGAN PROSES FOTOKATALISIS SINAR MATAHARI MENGGUNAKAN KATALIS C,N-CODOPED $\mathrm{TiO}_{2}$
}

\author{
Khoiriah Khoiriah ${ }^{1}$, Diana Vanda Wellia ${ }^{2}$, dan Safni Safni ${ }^{1}$ \\ ${ }^{1}$ Laboratorium Kimia Analisis Terapan, Jurusan Kimia, Fakultas Matematikan dan IImu Pengetahuan \\ Alam, Universitas Andalas, Padang 25163, Indonesia \\ 2 Laboratorium Kimia Material, Jurusan Kimia, Fakultas Matematikan dan IImu Pengetahuan Alam, \\ Universitas Andalas, Padang 25163, Indonesia \\ E-mail : safni@sci.unand.ac.id
}

Received : 24 April 2018; revised : 30 Mei 2018; accepted : 26 November 2018

\begin{abstract}
ABSTRAK
DEGRADASI PESTISIDA DIAZINON DENGAN PROSES FOTOKATALISIS SINAR MATAHARI

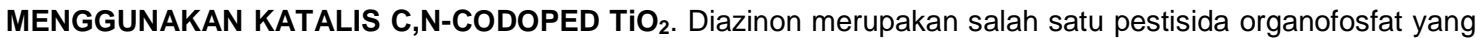
sangat luas penggunaannya di bidang pertanian, namun ia bersifat sangat beracun. Pada penelitian ini diazinon didegradasi secara fotokatalisis menggunakakan katalis $\mathrm{C}, \mathrm{N}$-codoped $\mathrm{TiO}_{2}$ yang aktif pada sinar matahari. Beberapa faktor yang mempengaruhi proses degradasi dipelajari seperti massa katalis, pengaruh doping pada titania, $\mathrm{pH}$ larutan awal, dan waktu irradiasi. Penambahan katalis $\mathrm{C}, \mathrm{N}$-codoped $\mathrm{TiO}_{2}$ mampu meningkatkan persen degradasi diazinon secara siginifikan. Diazinon dengan konsentrasi awal $18 \mathrm{mg} / \mathrm{l}$ dan volume $20 \mathrm{ml}$ terdegradasi sebesar 90,75\% pada kondisi optimum pH 7, 12 mg katalis $\mathrm{C}, \mathrm{N}$-codoped $\mathrm{TiO}_{2}$, selama 300 menit fotokatalisis sinar matahari. Data hasil analisis High Performance Liquid Chromatography (HPLC) menunjukkan bahwa diazinon telah berhasil didegradasi.
\end{abstract}

Kata kunci : Degradasi, Fotokatalisis, Diazinon, $\mathrm{C}, \mathrm{N}-$ codoped $\mathrm{TiO}_{2}$

\section{ABSTRACT}

DEGRADATION OF DIAZINON PESTICIDE BY SOLAR-LIGHT PHOTOCATALYSIS USING C,N-CODOPED $\mathrm{TiO}_{2}$ CATALYST. Diazinon is one of the most widely used organophosphate pesticides in agriculture, but it is highly toxic. In this study, diazinon was degraded by photocatalysis using an activated $\mathrm{C}, \mathrm{N}$-codoped $\mathrm{TiO}_{2} \mathrm{Catalyst}$ under solar-light irradiation. Several factors affecting the degradation process were investigated such as mass of the catalyst, the effect of doping on titania, the $\mathrm{pH}$ of the initial solution, and irradiation time. The addition of a $\mathrm{C}, \mathrm{N}$-codoped $\mathrm{TiO}_{2}$ catalyst was able to significantly increase diazinon degradation percentage. $20 \mathrm{~mL} \mathrm{of} 18 \mathrm{mg} / \mathrm{L}$ diazinon was degraded by $90.75 \%$ under optimum conditions $\mathrm{pH} \mathrm{7,12} \mathrm{mg} \mathrm{of} \mathrm{C,N-codoped} \mathrm{TiO}_{2}$ catalyst within 300 min solar-light photocatalysis. HPLC analysis results showed that diazinon was successfully degraded.

Keywords : Degradation, Photocatalysis, Diazinon, $\mathrm{C}, \mathrm{N}$-codoped $\mathrm{TiO}_{2}$

\section{PENDAHULUAN}

Pestisida organofosfat adalah senyawa kimia yang banyak digunakan khususnya di bidang perkebunan dan pertanian. Salah satu jenis pestisida organofosfat yang sangat luas penggunaannya adalah berbahan aktif diazinon karena mudah didapatkan, serta efektif membunuh hama pada tanaman padi, jagung, kentang, dan buah-buahan (Aggarwal et al. 2013). Namun penggunaan yang berkelanjutan menyebabkan konsentrasi dan jumlahnya di lingkungan semakin meningkat. Hal ini tentu akan meresahkan komponen lingkungan. Jenis pestisida ini sangat beracun terutama bagi manusia dan hewan mamalia lainnya. la akan menghambat kerja enzim asetilkolinesterase pada sistem saraf (Karanth 2014) bahkan bisa menyebabkan kematian pada manusia. Oleh sebab itu, konsentrasi limbah dan residu pestisida organofosfat di lingkungan harus dikurangi atau diturunkan.

Beberapa metode untuk mengatasi limbah dan residu pestisida diazinon telah banyak dilakukan diantaranya biodegradasi (Kurade et al. 2016), adsorpsi (Moussavi, Hosseini, and Alahabadi 2013), membran filtrasi, dan oksidasi secara elektrokimia (Lazarević-Pašti et al. 2013). Metode-metode tersebut bersifat non-destructive, dan hanya dapat mengubah 
limbah ke dalam fase yang lain sehingga tetap menghasilkan efek samping dan limbah baru (Zhou 2013).

Metode advanced Oxidation Processes (AOPs) telah banyak dikembangkan untuk mendegradasi pestisida diazinon di perairan seperti fotolisis (Shemer and Linden 2006), ozonolisis (Wu, Lan, and Chan 2009) dan sonolisis (Wang and Shih 2016). Metode-metode tersebut menghasilkan dan menggunakan radikal $\cdot \mathrm{OH}$ dan $\bullet \mathrm{O}_{2}$ sebagai agen reduktor dan oksidator untuk mendegradasi polutan organik menjadi senyawa yang lebih ramah lingkungan seperti $\mathrm{H}_{2} \mathrm{O}$ dan $\mathrm{CO}_{2}$. Telah dilaporkan efektivitas metode-metode tersebut semakin meningkat dengan adanya penambahan fotokatalis semikonduktor yang akan memberikan sinergisitas dalam penyumbangan radikal $\cdot \mathrm{OH}$ (Mirmasoomi, Ghazi, and Galedari 2017); (Beduk, Aydin, and Ozcan 2012).

Fotokatalis yang sering digunakan pada proses degradasi adalah $\mathrm{TiO}_{2}$ karena kelimpahannya yang cukup banyak, efektif, stabil terhadap fotokorosi, serta tidak beracun bagi makhluk hidup (Sakkas et al. 2005). Namun ia memiliki band gap yang cukup tinggi $(3,2 \mathrm{eV})$ dan banyak penelitian telah dilakukan untuk memperkecil band gapnya dengan cara memodifikasi $\mathrm{TiO}_{2}$ dengan unsur logam, ataupun nonlogam seperti karbon, nitrogen, dan yetrium (Daghrir, Drogui, and Robert 2013). Hal ini bertujuan agar proses degradasi semakin efektif.

Memodifikasi $\mathrm{TiO}_{2}$ dengan cara co-doped menjadi salah satu pilihan karena dapat meningkatkan aktivitas fotokatalitiknya di daerah sinar tampak lebih tinggi dibandingkan dengan hasil doping hanya dengan satu unsur (Xu et al. 2011). Beberapa peneliti telah mencoba memodifikasi fotokatalis $\mathrm{TiO}_{2}$ untuk proses degradasi pestisida diazinon seperti yang dilaporkan oleh Baneshi memodifikasi $\mathrm{TiO}_{2}$ dengan cara doping menggunakan besi (Fe) (Baneshi et al. 2017). Hossaini memodifikasi $\mathrm{TiO}_{2}$ dengan cara pendopingan menggunakan tiga unsur; besi, fluor, nitrogen dan sulfur yang diaktifkan dibawah lampu LED (Hossaini, Moussavi, and Farrokhi 2014). Aktivitas fotokatalis hasil modifikasi $\mathrm{TiO}_{2}$ terbukti meningkatkan efektivitas proses degradasi diazinon. Unsur potensial yang bisa digunakan sebagai dopan adalah karbon dan nitrogen karena ukuran dan jari-jarinya tidak jauh berbeda dengan oksigen (Safni et al. 2015a). Beberapa metode sintesis $\mathrm{C}, \mathrm{N}$-codoped $\mathrm{TiO}_{2}$ telah dilaporkan seperti sol-gel (Kakroudi, Kazemi, and Kaboudin 2014); (Chen et al. 2007); (Liu et al. 2013) solvotermal (Dai et al. 2013); (Wu and Ju 2014); (El-Sheikh et al. 2017); (Wang and Lim 2010) namun metodemetode tersebut masih menggunakan pelarut organik sehingga kurang ramah lingkungan dan membutuhkan biaya yang cukup tinggi.
Hasil modifikasi $\mathrm{TiO}_{2}$ dengan karbon dan nitrogen ( $\mathrm{C}, \mathrm{N}$-codoped $\left.\mathrm{TiO}_{2}\right)$ telah berhasil disintesis dengan metode peroxo sol-gel tanpa menggunakan pelarut organik dan lebih ramah lingkungan (Xu et al. 2011); (Wellia, Fitria, and Safni 2018) dan dilaporkan bahwa kehadiran dopan karbon dan nitrogen terbukti memberikan efek sinergisitas dalam menyerap sinar tampak untuk meningkatkan aktivitas fotokatalitik titania. Aplikasinya juga telah dilakukan terhadap beberapa polutan organik (Safni et al. 2015); (Fitriyani et al. 2017); (Safitri et al. 2017); (Safni et al. 2016); (M. Safni et al. 2017) maupun anorganik (Wellia, Fitria, and Safni 2018) dan sejauh ini belum ada laporan yang mengaplikasikan katalis $\mathrm{C}, \mathrm{N}$-codoped $\mathrm{TiO}_{2}$ yang disintesis dengan metode peroxo sol-gel dalam mendegradasi pestisida diazinon secara fotokatalisis di bawah sinar matahari. Tujuan penelitian ini adalah mendegradasi pestisida diazinon secara fotokatalisis menggunakan katalis $\mathrm{C}, \mathrm{N}$-codoped $\mathrm{TiO}_{2}$ di bawah sinar matahari. Beberapa parameter yang mempengaruhi proses degradasi dipelajari seperti; massa katalis, pengaruh doping pada titania, $\mathrm{pH}$ larutan awal, dan waktu irradiasi.

\section{BAHAN DAN METODE}

\section{Bahan}

Peralatan yang digunakan adalah spektrofotometer (Shimadzu Corp, serial A116352, Japan), centrifuge (Nesco 80-2), HPLC (Hitachi-Trimaide, serial 1202-005, Japan), Whatman filter ( : $0.22 \mu \mathrm{m})$, dan peralatan gelas.

Bahan kimia yang digunanakan adalah pestisida komersial berbahan aktif diazinon (Diazinon 600 EC) dari PT. Petrokimia Kayaku, akuabides, etanol (96\%), natrium hidroksida (Merck), asetonitril (HPLC Grade), dan asam klorida (Merck). Katalis $\mathrm{TiO}_{2}$ dan $\mathrm{C}, \mathrm{N}$-codoped $\mathrm{TiO}_{2}$ dari laboratorium analitik terapan Universitas Andalas.

\section{Metode}

Katalis C,N-codoped $\mathrm{TiO}_{2}$ disintesis dengan metode peroxo sol-gel. Karbon dari tempurung kelapa, amonia dan $\mathrm{TiCL}_{4}$ digunakan sebagai prekursor karbon, nitrogen dan titania. Pada metode ini, pelarut yang digunakan adalah air sehingga bebas dari senyawa organik. Prosedur sintesis katalis mengacu pada cara kerja yang telah dikerjakan oleh Wellia, Fitria, dan Safni (2018) serta Xu et al (2011).

Fotokatalisis dilakukan pada pestisida diazinon komersial dengan konsentrasi $18 \mathrm{mg} / \mathrm{l}$ yang dipersiapkan dari larutan stok $6000 \mathrm{mg} / \mathrm{l}$ dengan pelarut campuran etanol dan air $(7 / 3, v / v)$. Larutan $20 \mathrm{ml}$ diazinon dimasukkan ke dalam petridish (diameter $10 \mathrm{~cm}$ ) kemudian ditambahkan sejumlah katalis. Campuran 
disinari dengan sinar matahari. Larutan yang sudah didegradasi disentrifugasi selama 20 menit dengan kecepatan 3000 rpm untuk memisahkan katalis dari larutan dan disaring dengan kertas saring Whatman 0,22 $\mu \mathrm{m}$. Filtrat dimasukkan ke dalam botol vial gelap dan diukur dengan spektrofotometer UV-Vis pada panjang gelombang $247 \mathrm{~nm}$. Pengaruh penambahan jumlah massa katalis dipelajari dengan variasi $0 \mathrm{mg}, 6 \mathrm{mg}, 12 \mathrm{mg}, 18 \mathrm{mg}$, dan $24 \mathrm{mg}$. Variasi $\mathrm{pH}$ larutan awal $(\mathrm{pH} \mathrm{3,} \mathrm{pH} 5, \mathrm{pH} 7, \mathrm{pH} 11)$ yang diatur dengan penambahan larutan $\mathrm{NaOH}$ $(0,01 \mathrm{~N})$ atau $\mathrm{HCl}(0,01 \mathrm{~N})$. Pada variasi massa katalis dan $\mathrm{pH}$ larutan awal, konsentrasi awal diazinon $18 \mathrm{mg} / \mathrm{L}$ yang disinari selama 150 menit. Kemampuan adsorpsi katalis, fotolisis matahari dan fotokatalisis menggunakan katalis $\mathrm{TiO}_{2}$ juga dilakukan sebagai pembanding atau kontrol. Persen degradasi dihitung menggunakan persamaan di bawah ini:

$$
\frac{A_{i}-A_{f}}{A_{i}} X 100 \%
$$

dimana $A_{i}$ dan $A_{f}$ merupakan absorban awal dan absorban akhir dari pestisida diazinon.

Degradasi diazinon di bawah sinar matahari dilakukan dibawah sinar matahari langsung pada pukul 10.30 - 15.30 siang pada kondisi matahari bersinar cerah tanpa berawan dengan intesitas (90000 lux hingga 140000 lux) suhu $\left(27^{\circ} \mathrm{C}\right.$ sampai $\left.33^{\circ} \mathrm{C}\right)$. Intensitas diukur dengan aplikasi luxmeter pada smartphone. Larutan diazinon yang telah didegradasi secara fotokatalisis menggunakan $12 \mathrm{mg}$ katalis C,N-codoped $\mathrm{TiO}_{2}$ yang disinari dengan sinar matahari selama 300 menit juga diukur dengan HPLC untuk mengetahui apakah setelah proses fotokatalisis terbentuk senyawa intermediet pestisida diazinon atau tidak.

Larutan pestisida diazinon sebelum dan sesudah didegradasi secara fotokatalisis matahari menggunakan $12 \mathrm{mg}$ katalis $\mathrm{C}, \mathrm{N}$-codoped $\mathrm{TiO}_{2}$ selama 300 menit diukur menggunakan HPLC dengan detektor UV pada panjang gelombang $247 \mathrm{~nm}$. HPLC dilengkapi dengan kolom C18 (150 mm x 4,6 mm). Fase gerak yang digunakan adalah campuran asetonitril dan akuabides (75/25, v/v), laju alir $0,6 \mathrm{ml} / \mathrm{min}$, dan volume injeksi sebesar $20 \mathrm{I}$.

\section{HASIL DAN PEMBAHASAN}

\section{Pengaruh Penambahan Jumlah Massa Katalis Terhadap Degradasi Diazinon}

Pengaruh penambahan jumlah katalis terhadap persen degradasi pestisida diazinon ditampilkan pada Gambar 1. Pada penambahan $6 \mathrm{mg}$ hingga $12 \mathrm{mg}$ katalis $\mathrm{C}, \mathrm{N}$-codoped $\mathrm{TiO}_{2}$ terjadi peningkatan persen degradasi dari 47,3\% menjadi 50,93\%. Namun, terjadi penurunan ketika ditambah katalis sebanyak $18 \mathrm{mg}$ dan $24 \mathrm{mg}$. Berdasarkan hasil, massa katalis optimum terdapat pada penambahan $12 \mathrm{mg}$ katalis. Jumlah katalis yang digunakan adalah faktor penentu kadar spesies reaktif yang dihasilkan di dalam proses degradasi (Safni, Desmiati, and Suyani 2009); (Zilfa et al. 2011); (Fitriyani et al. 2017). Namun penggunaan katalis lebih dari massa optimum akan menyebabkan proses degradasi menjadi terhambat yang disebabkan oleh aglomerasi katalis, efek hamburan cahaya (Hossaini, Moussavi, and Farrokhi 2014), serta berkurangnya penentrasi foton dari sinar terhadap larutan diazinon. Oleh sebab itu, penambahan $12 \mathrm{mg}$ katalis $\mathrm{C}, \mathrm{N}$-codoped $\mathrm{TiO}_{2}$ dipilih untuk pengerjaan parameter selanjutnya.

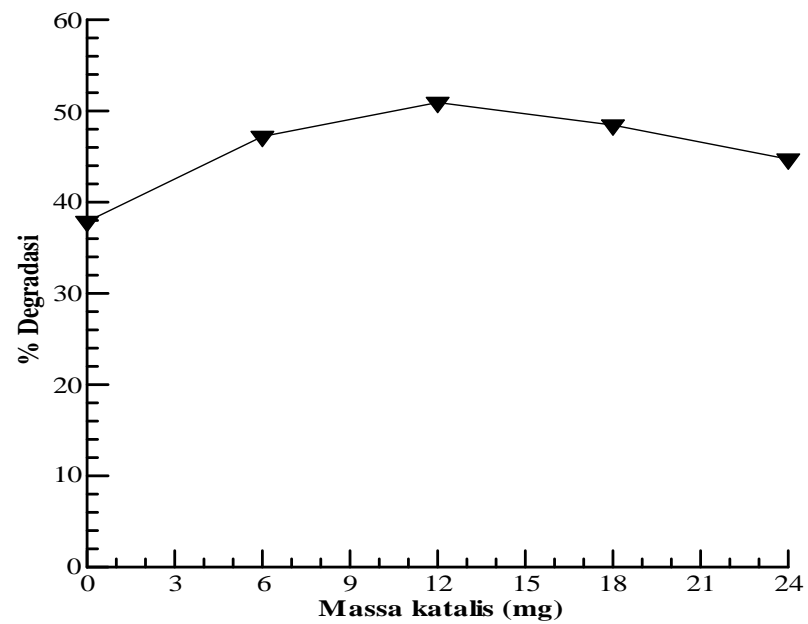

Gambar 1. Pengaruh penambahan jumlah massa katalis $\mathrm{C}, \mathrm{N}$-codoped $\mathrm{TiO}_{2}(0 \mathrm{mg}, 6 \mathrm{mg}, 12 \mathrm{mg}, 18 \mathrm{mg}, 24 \mathrm{mg})$ terhadap degradasi $18 \mathrm{mg} / \mathrm{L}$ diazinon secara fotokatalisis sinar matahari selama 150 menit (pukul 10.37-13.07, intensitas 70000 lux sampai dengan 90000 lux) 


\section{Pengaruh Doping Titania Terhadap Degradasi Diazinon}

Gambar 2. menampilkan pengaruh pendopingan karbon dan nitrogen pada titania terhadap degradasi pestisida diazinon. Berdasar hasil, dapat dilihat bahwa diazinon terdegradasi lebih banyak ketika didegradasi secara fotokatalisis sinar matahari menggunakan katalis modifikasi $\mathrm{TiO}_{2} \quad$ (C,N-codoped $\mathrm{TiO}_{2}$ ) dibandingkan penggunaan katalis titania $\left(\mathrm{TiO}_{2}\right)$ dengan nilai efisiensi sebesar $84,93 \%$ dan $79,14 \%$ secara berurutan. Hasil ini membuktikan bahwa modifikasi $\mathrm{TiO}_{2}$ dengan karbon dan nitrogen mampu meningkatkan katalitik dari $\mathrm{TiO}_{2}$ dengan cara penurunan band gap $\mathrm{TiO}_{2}$ dari $3.09 \mathrm{eV}$ menjadi $2.87 \mathrm{eV}$ (Wellia, Fitria, and Safni 2018).

Pada studi juga diuji adsorpsi katalis dan fotolisis sinar matahari (tanpa katalis) sebagai pembanding. Persen adsorpsi dan fotolisis selama 180 menit terhadap diazinon secara berurutan yaitu $20 \%$ dan $45,51 \%$. Mekanisme pengurangan konsentrasi diazinon pada sistem tanpa penambahan katalis adalah fotolisis langsung oleh sinar matahari (Niknafs et al. 2013). Ku dkk (1998) juga melaporkan bahwa sinar simulasi matahari $(\lambda=290 \mathrm{~nm}$ hingga $790 \mathrm{~nm}$ ) mampu mendegradasi diazinon dengan mekanisme fotolisis (Ku and Chang 1998). Hal yang sama juga dilakukan oleh Assalin dkk (2016) menggunakan sinar matahari langsung untuk mendegradasi pestisida metil paration dengan persen degradasi sebesar 39,4\% selama 90 menit fotolisis (Assalin et al. 2016), terdapat peningkatan persen degradasi yang cukup signifikan pada fotokatalisis $(84,93 \%)$ dibandingkan fotolisis saja $(45,51 \%)$. Kehadiran katalis dalam sistem fotokatalisis memberikan sinergisitas yang tinggi dalam menghasilkan radikal $\cdot \mathrm{OH}$ untuk mendegradasi diazinon sehingga persen degradasi diazinon menjadi meningkat secara signifikan.

Nilai efisiensi degradasi diazinon setelah fotokatalisis 150 menit adalah 50,93\% (Gambar 1) dan mencapai $78,80 \%$ hanya dengan 120 menit fotokatalisis (Gambar 2). Hal ini disebabkan oleh adanya perbedaan intensitas dari matahari, pada saat eksperimen Gambar 2 intensitas matahari 90000 lux hingga 140000 lux sedangkan pada saat pengerjaan eksperimen Gambar 1, matahari memiliki intesitas sebesar 70000 lux hingga 90000 lux.

\section{Pengaruh Ph Larutan Awal Terhadap Degradasi Diazinon}

Pengaruh $\mathrm{pH}$ terhadap degradasi pestisida diazinon ditampilkan pada Gambar 3 dengan parameter yang lainnya tetap konstan (konsentrasi awal diazinon $18 \mathrm{mg} / \mathrm{l}, 12 \mathrm{mg}$ katalis, dan waktu penyinaran selama 150 menit). Persen degradasi meningkat dari $37,09 \%$ hingga $61,58 \%$ pada $\mathrm{pH} 3$ sampai $\mathrm{pH} 7$ dan terjadi penurunan pada $\mathrm{pH} 11$, sehingga disimpulkan bahwa pH optimum diazinon terdegradasi secara fotokatalisis sinar matahari pada $\mathrm{pH}$ 7. Hasil yang sama juga didapatkan dan dilaporkan oleh beberapa peneliti dalam mendegradasi diazinon secara fotokatalisis menggunakan katalis $\mathrm{Fe}$-doped $\mathrm{TiO}_{2}$, FeFNS- $\mathrm{TiO}_{2}$, dan Ni-doped ZnO (Baneshi et al. 2017); (Hossaini, Moussavi, and Farrokhi 2014); (Jonidi-Jafari et al. 2017).

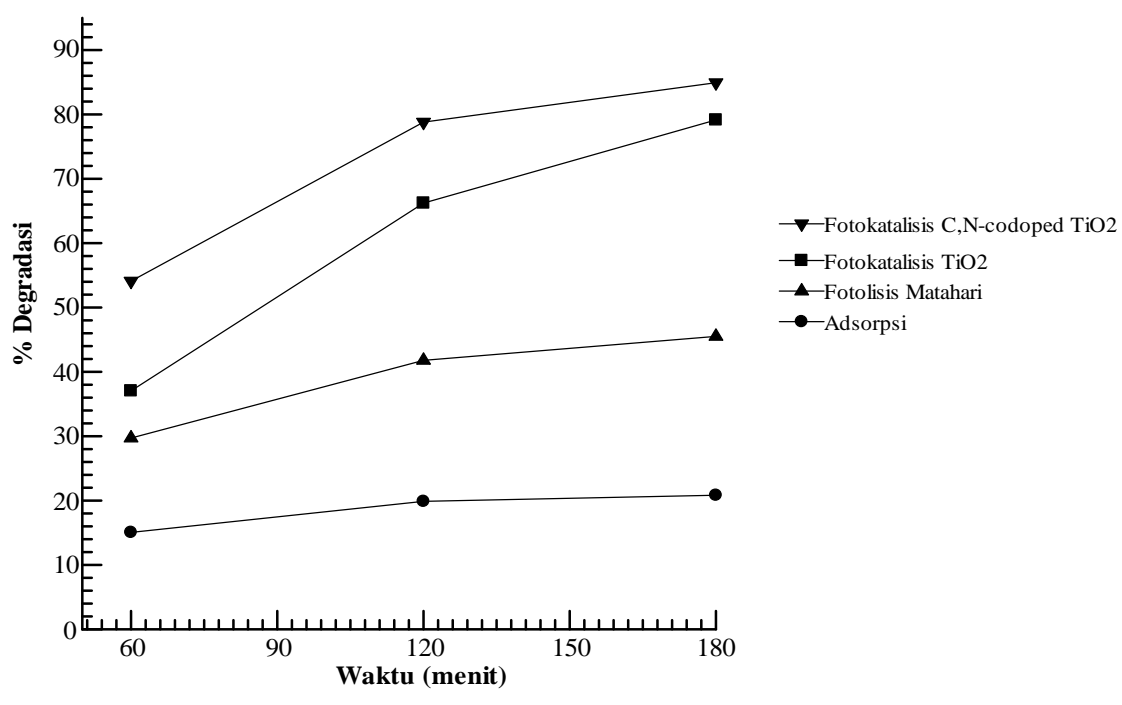

Gambar 2. Pengaruh doping pada $\mathrm{TiO}_{2}$ terhadap degradasi $18 \mathrm{mg} / \mathrm{l}$ diazinon secara fotokatalisis sinar matahari dengan intesitas 90000 hingga 140000 selama (60 menit, 120 menit, 180 menit) 
$\mathrm{pH}$ point of zero charge (pzc) dari katalis $\mathrm{TiO}_{2}$ berkisar dari 6,3 hingga 6,9. Permukaan katalis $\mathrm{TiO}_{2}$ bermuatan negatif ketika $\mathrm{pH}>p z c$, positif pada $\mathrm{pH}<p z c$ dan bersifat netral pada $\mathrm{pH} \approx p z c$. Pengaruh $\mathrm{pH}$ pada proses fotokatalisis bisa dijelaskan dari pengaruh interaksi elektrostatik antara permukaan katalis dan senyawa target. Nilai pKa diazinon adalah 2,6, diazinon bermuatan negatif pada $\mathrm{pH}>\mathrm{pKa}$ dan katalis bermuatan posistif pada $\mathrm{pH}<6.9$ sehingga diharapkan $\mathrm{pH}$ optimal terdapat pada kondisi katalis bermuatan posistif dan diazinon bermuatan negatif (Baneshi et al. 2017); (Hossaini, Moussavi, and Farrokhi 2014); (Wang and Lim 2010).
Gambar 4 memperlihatkan pengaruh waktu terhadap degradasi diazinon. Semakin lama waktu penyinaran, semakin tinggi persen degradasi diazinon. Persen degradasi diazinon untuk pada waktu 30 menit hingga 300 menit secara berututan yaitu; dari $27,21 \%$ menjadi $90,75 \%$ di bawah sinar matahari. Hal ini disebabkan oleh kontak antara katalis dan sinar semakin efektif, foton yang diserap oleh katalis semakin banyak, proses produksi hole dan radikal $\cdot \mathrm{OH}$ semakin tinggi (Safni et al. 2016); (Safitri et al. 2017); (Safni et al. 2017) sehingga proses degradasi diazinon menjadi semakin efektif pada waktu penyinaran yang lebih lama.

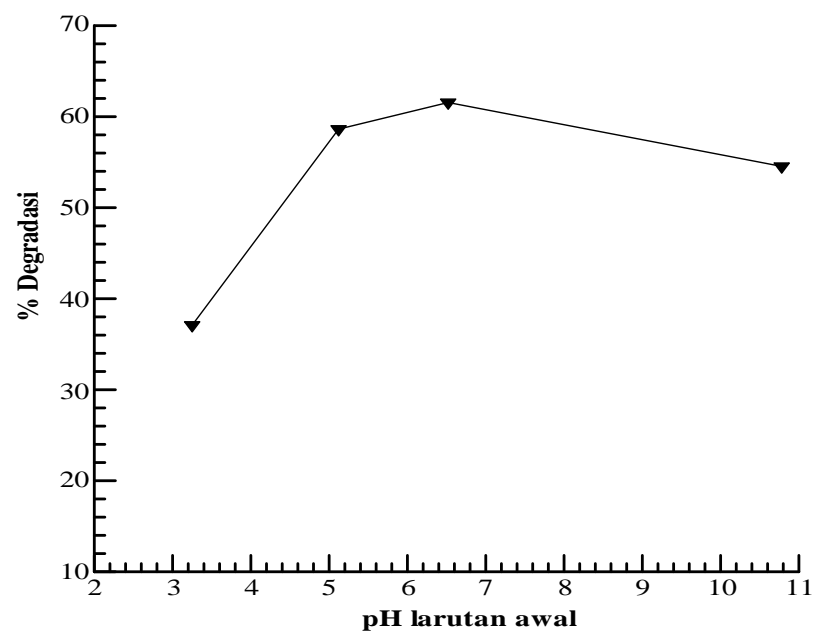

Gambar 3. Pengaruh $\mathrm{pH}$ larutan awal $(3,5,7,11)$ terhadap degradasi $18 \mathrm{mg} / \mathrm{l}$ diazinon secara fotokatalisis sinar matahari menggunakan $12 \mathrm{mg} \mathrm{C,N-codoped} \mathrm{TiO}_{2}$ selama 150 menit

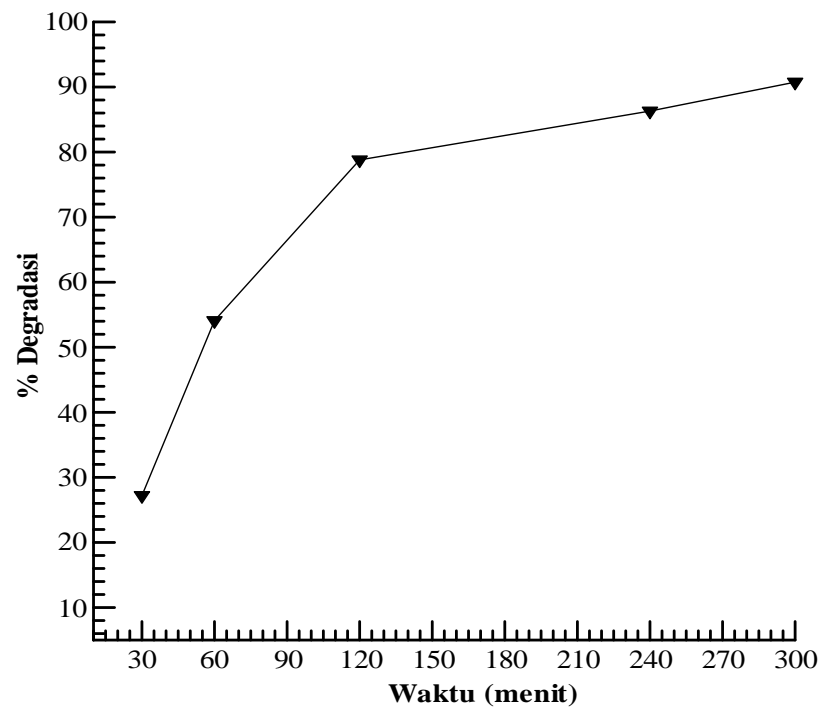

Gambar 4. Pengaruh waktu irradiasi terhadap degradasi $18 \mathrm{mg} / \mathrm{L}$ diazinon secara fotokatalisis menggunakan $12 \mathrm{mg} \mathrm{C,N-codoped} \mathrm{TiO}_{2}$ selama (30 menit, 60 menit, 120 menit, 240 menit, dan 300 menit dengan intensitas matahari 90000 lux sampai dengan 140000 lux) 


\section{Analisis HPLC}

Perbandingan kromatogram pestisida diazinon sebelum dan sesudah didegradasi bisa dilihat pada Gambar 5. Puncak diazinon muncul pada waktu retensi $t_{R}=8.653 \mathrm{~min}$ (sesuai dengan standar diazinon). Intensitas puncak menurun setelah difotokatalisis menggunakan $12 \mathrm{mg}$ katalis $\mathrm{C}, \mathrm{N}$-codoped $\mathrm{TiO}_{2}$ selama 300 menit dibawah sinar matahari (Gambar 5b). $\mathrm{Hal}$ ini mengindikasikan bahwa diazinon telah berhasil didegradasi. Namun, pada kromatogram muncul puncak baru di waktu retensi $t_{R}=1.4 \mathrm{~min}$ dan 2.2 min yang kemungkinan merupakan produk intermediet hasil degradasi diazinon yang perlu dianalisis dan dipelajari lebih lanjut. Beberapa peneliti telah mendegradasi diazinon secara fotokatalisis dan melaporkan intermediet yang terbentuk

seperti 2-isopropyl-6-methylpyrimidin-4-ol (IMP), diazoxon, dan hydroxydiazinon (Sakkas et al. 2005); (Nakaoka et al. 2010); (Kalantary et al. 2014).

Radikal $\cdot \mathrm{OH}$ bersifat non-selective dalam mengoksidasi polutan organik (Ahmed et al. 2011). Dalam hal ini ia mampu mengoksidasi bukan hanya senyawa target (diazinon) tetapi juga senyawa lainnya (senyawa pencampur yang ada di dalam pestisida komersial), yang dibuktikan oleh data hasil analisis HPLC. Pada kromatogram larutan awal diazinon (Gambar 5a) juga terdapat puncak lain pada waktu retensi $t_{R}=4.96$ min dan $t_{R}=5.38$ min yang kemungkinan merupakan senyawa campuran dari pestisida komersial yang digunakan. Setelah didegradasi, kedua puncak tersebut mengalami penurunan intensitas (Gambar 5b).
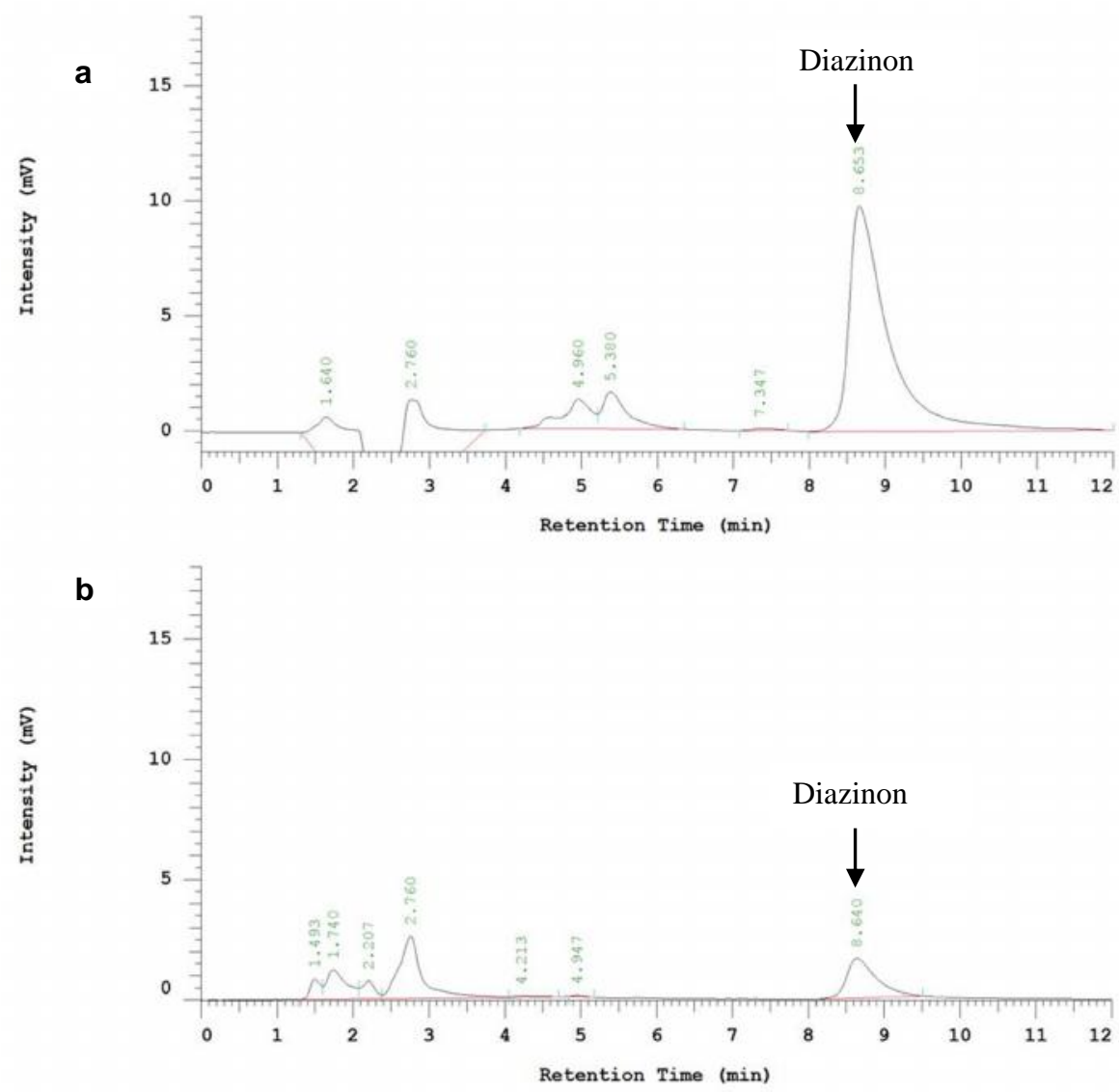

Gambar 5. Kromatogram larutan $18 \mathrm{mg} / \mathrm{L}$ diazinon (a) sebelum dan (b) setelah didegradasi secara fotokatalisis matahari menggunakan $12 \mathrm{mg} \mathrm{C,N-codoped} \mathrm{TiO}_{2}$ selama 300 menit 


\section{KESIMPULAN}

Pestisida diazinon telah berhasil didegradasi secara fotokatalisis menggunakan titania termodifikasi (C,N-codoped $\left.\mathrm{TiO}_{2}\right)$ di bawah sinar matahari. Kehadiran katalis di dalam sistem fotolisis diazinon mampu meningkatkan persen degradasi dari 45,51\% menjadi $84,93 \%$. Massa katalis, doping pada titania, $\mathrm{pH}$ larutan awal dan waktu penyinaran memberikan pengaruh yang cukup signifikan dalam proses fotokatalisis diazinon. Massa katalis dan $\mathrm{pH}$ larutan awal optimum yang didapatkan adalah $12 \mathrm{mg}$ dan $\mathrm{pH} 7$. Penambahan waktu penyinaran mampu meningkatkan persen degradasi diazinon. Dari hasil analisis HPLC mengindikasikan bahwa diazinon telah berhasil didegradasi yang perlu dianalisis dan dipelajari lebih lanjut.

\section{UCAPAN TERIMA KASIH}

Penulis menyampaikan terima kasih kepada Kementerian Riset, Teknologi, dan Pendidikan Tinggi Republik Indonesia (Kemenristekdikti) atas dukungan finansial dalam penelitian ini melalui Program Pendidikan Magister Menuju Doktor untuk Sarjana (nomor Hibah. 15 /UN.16. 17/PP. PMDSU/LPPM/2018).

\section{DAFTAR PUSTAKA}

Aggarwal, V., X Deng, A Tuli, and K. S. Goh. 2013. "Diazinon-Chemistry and Environmental Fate: A California." Edited by D.M. Whitacre. Reviews of Environmental Contamination and Toxicology. Reviews of. Vol. 233. doi:10.1007/978-1-4614-5577-6_5.

Ahmed, S., M. G. Rasul, R. Brown, and M. A. Hashib. 2011. "Influence of Parameters on the Heterogeneous Photocatalytic Degradation of Pesticides and Phenolic Contaminants in Wastewater: A Short Review." Journal of Environmental Management 92 (3). Elsevier Ltd: 311-30. doi:10.1016/j.jenvman.2010.08.028.

Assalin, M. R., V. L. Ferracini, S. N. C. Queiroz, C. M. Jonsson, Z. Clemente, and S. R. C. M. Silva. 2016. "Photocatalytic Degradation of an Organophosphorus Pesticide from Agricultural Waste by Immobilized $\mathrm{TiO}_{2}$ under Solar Radiation" 11 (4): 778-87. doi:10.4136/1980-993X.

Baneshi, M. M., S. Rezaei, A. Sadat, A Mousavizadeh, M. Barafrashtehpour, and H. Hekmatmanesh. 2017. "Investigation of Photocatalytic Degradation of Diazinon Using Titanium Dioxide $\left(\mathrm{TiO}_{2}\right)$ Nanoparticles Doped with Iron in the Presence of Ultraviolet Rays from the Aqueous Solution." Bioscience
Biotechnology Research Communication, no. 1: 60-67.

Beduk, F., M. E Aydin, and S. Ozcan. 2012. "Degradation of Malathion and Parathion by Ozonation, Photolytic Ozonation, and Heterogeneous Catalytic Ozonation Processes." Clean - Soil, Air, Water 40 (2): 179-87. doi:10.1002/clen.201100063.

Chen, D., Z. Jiang, J. Geng, Q. Wang, and D. Yang. 2007. "Carbon and Nitrogen CoDoped $\mathrm{TiO}_{2}$ with Enhanced Visible-Light Photocatalytic Activity." Ind. Eng. Chem. $\begin{array}{lll}\text { Res } \quad 46 \quad \text { (9): } & \text { 2741-46. }\end{array}$ doi:10.1021/ie061491k.

Daghrir, R., P. Drogui, and D. Robert. 2013. "Modified $\mathrm{TiO}_{2}$ for Environmental Photocatalytic Applications: A Review." Industrial and Engineering Chemistry Research 52 (10): 3581-99. doi:10.1021/ie303468t.

Dai, G., S. Liu, Y. Liang, H. Liu, and Z Zhong. 2013. "A Simple Preparation of Carbon and Nitrogen Co-Doped Nanoscaled $\mathrm{TiO}_{2}$ with Exposed \{001\} Facets for Enhanced Visible-Light Photocatalytic Activity." Journal of Molecular Catalysis A: Chemical 368-369. Elsevier B.V.: 38-42. doi:10.1016/j.molcata.2012.11.014.

El-Sheikh, S. M., Tamer M. Khedr, Amer Hakki, Adel A. Ismail, Waheed A. Badawy, and Detlef W. Bahnemann. 2017. "Visible Light Activated Carbon and Nitrogen Co-Doped Mesoporous $\mathrm{TiO}_{2}$ as Efficient Photocatalyst for Degradation of Ibuprofen." Separation and Purification Technology 173: 258-68. doi:10.1016/j.seppur.2016.09.034.

Fitriyani, Y. O., U. Septiani, D. V. Wellia, R. A Putri, and S. Safni. 2017. "Degradasi Zat Warna Direct Red-23 Secara Fotolisis Dengan Katalis C-N- Degradation of Direct Red-23 Dye by Photolysis with The Addition of $\mathrm{C}-\mathrm{N}$ - Codoped $\mathrm{TiO}_{2}$ Catalyst" 3 (2): 153-60.

Hossaini, H., G. Moussavi, and M. Farrokhi. 2014. "The Investigation of the LEDActivated FeFNS- $\mathrm{TiO}_{2}$ Nanocatalyst for Photocatalytic Degradation and Mineralization of Organophosphate Pesticides in Water." Water Research 59. Elsevier Ltd: 130-44. doi:10.1016/j.watres.2014.04.009.

Jonidi-Jafari, A., M. Gholami, M. Farzadkia, A. Esrafili, and M. Shirzad-Siboni. 2017. "Application of Ni-Doped ZnO Nanorods for Degradation of Diazinon: Kinetics and by-Products." Separation Science and Technology (Philadelphia) 52 (15): 23952406.doi:10.1080/01496395.2017.130350

Kakroudi, M. A., F. Kazemi, and B. Kaboudin. 2014. "Highly Efficient Photodeoximation 
under Green and Blue LEDs Catalyzed by Mesoporous CN Codoped Nano $\mathrm{TiO}_{2}$." Journal of Molecular Catalysis $A$ : Chemical 392. Elsevier B.V.: 112-19. doi:10.1016/j.molcata.2014.04.036.

Kalantary, R. R., Y. D. Shahamat, M. Farzadkia, A. Esrafili, and H. Asgharnia. 2014. "Photocatalytic Degradation and Mineralization of Diazinon in Aqueous Solution Using Nano- $\mathrm{TiO}_{2}$ (Degussa, P25): Kinetic and Statistical Analysis." Desalination and Water Treatment, 1-9. doi:10.1080/19443994.2014.928795.

Karanth, S. 2014. "Diazinon." Encyclopedia of Toxicology: Third Edition 2: 55-56. doi:10.1016/B978-0-12-386454-3.001251.

Ku, Y., and J. Chang. 1998. "Effect of Solution $\mathrm{PH}$ on the Hydrolysis and Photolysis of Diazinon in Aqueous Solution." Water, Air, and Soil Pollution 108: 445-56.

Kurade, M. B., J. R. Kim, S. P. Govindwar, and B. Jeon. 2016. "Insights into Microalgae Mediated Biodegradation of Diazinon by Chlorella Vulgaris: Microalgal Tolerance to Xenobiotic Pollutants and Metabolism." Algal Research 20. Elsevier B.V.: 126-34. doi:10.1016/j.algal.2016.10.003.

Lazarević-Pašti, T. D., A.M. Bondžić, I. A. Pašti, S.V. Mentus, and V. M. Vasić. 2013. "Electrochemical Oxidation of Diazinon in Aqueous Solutions via Electrogenerated Halogens - Diazinon Fate and Implications for Its Detection." Journal of Electroanalytical Chemistry 692: 40-45. doi:10.1016/j.jelechem.2013.01.005.

Liu, G., C. Han, M. Pelaez, D. Zhu, S. Liao, V. Likodimos, A. G. Kontos, P. Falaras, and D. D. Dionysiou. 2013. "Enhanced Visible Light Photocatalytic Activity of CNCodoped $\mathrm{TiO}_{2}$ Films for the Degradation of Microcystin-LR." Journal of Molecular Catalysis A: Chemical 372. Elsevier B.V.: 58-65.

doi:10.1016/j.molcata.2013.02.006.

Mirmasoomi, S. R., M. M Ghazi, and M. Galedari. 2017. "Photocatalytic Degradation of Diazinon under Visible Light Using $\mathrm{TiO}_{2} / \mathrm{Fe}_{2} \mathrm{O}_{3}$ nanocomposite Synthesized by Ultrasonic-Assisted Impregnation Method." Separation and Purification Technology 175. Elsevier B.V.: 418-27. doi:10.1016/j.seppur.2016.11.021.

Moussavi, G., H. Hosseini, and A. Alahabadi. 2013. "The Investigation of Diazinon Pesticide Removal from Contaminated Water by Adsorption onto $\mathrm{NH}_{4} \mathrm{Cl}$-Induced Activated Carbon." Chemical Engineering Journal 214. Elsevier B.V.: 172-79. doi:10.1016/j.cej.2012.10.034.

Nakaoka, Y., H. Katsumata, S. Kaneco, T.
Suzuki, and K. Ohta. 2010. "Photocatalytic Degradation of Diuron in Aqueous Solution by Platinized $\mathrm{TiO}_{2}$." Desalination and Water Treatment 13: 427-36. doi:10.1016/j.jhazmat.2009.06.110.

Niknafs, B. N., A. Ahmadi, R. Hajikhani, J. G. Mianjy, and Z. Ghorbankhani. 2013. "Photodegradation of Deltamethrin and Fenvalerate under Simulated Solar Light Irradiation and Identification of Photoproducts." Applied Ecology and Environmental Research 11 (1): 35-41.

Safitri, V. Y., A. Santoni, D.V. Wellia, K. Khoiriah, and S. Safni. 2017. "Degradation of Paracetamol by Photolysis Using C-NCodoped $\mathrm{TiO}_{2}$." Molekul 12 (2): 189-95. doi:10.20884/1.jm.2017.12.2.378.

Safni, Desmiati, and H. Suyani. 2009. "Degradasi Senyawa Dikofol Dalam Pestisida Kelthane 200 EC Secara Fotolisis Denagan Penambahan TiO2Anatase." Jurnal Riset Kimia 2 (2): 14048.

doi:https://doi.org/10.25077/jrk.v2i2.154.

Safni, M., R.A Putri, D. V. Wellia, and U. Septiani. 2017. "Photodegradation of Orange F3R Dyes: Effect of Light Sources and the Addition of $\mathrm{C}, \mathrm{N}$-Codoped $\mathrm{TiO}_{2}$ Catalyst." Der Pharma Chemica 9 (10): 1-5.

Safni, S., D. V. Wellia, P. S. Komala, R. A. Putri, and Deliza. 2016. "Photocatalytic Degradation of Yellow-GCN Dye Using C$\mathrm{N}$-Codoped $\mathrm{TiO}_{2}$ Thin Film in Degradation Reactor Using Visible-Light Irradiation" 8 (19): 642-46. http://derpharmachemica.com/archive.htm I.

Safni, D. V. Wellia, P. S. Komala, and R. A Putri. 2015a. "Degradation of Yellow-GCN by Photolysis with UV-Light and Solar Irradiation Using C-N-Codoped $\mathrm{TiO}_{2}$ Catalyst." Journal of Chemical and Pharmaceutical Research 7 (11): 306-11.

Sakkas, V. A., A. Dimou, K. Pitarakis, G. Mantis, and T. Albanis. 2005. " $\mathrm{TiO}_{2}$ Photocatalyzed Degradation of Diazinon in an Aqueous Medium." Environmental Chemistry Letters 3 (2): 57-61. doi:10.1007/s10311-004-0091-6.

Shemer, H., and K. G. Linden. 2006. "Degradation and By-Product Formation of Diazinon in Water during UV and UV/ $\mathrm{H}_{2} \mathrm{O}_{2}$ Treatment." Journal of Hazardous Materials $136 \quad$ (3): $\quad$ 553-59. doi:10.1016/j.jhazmat.2005.12.028.

Wang, C., and Yi. Shih. 2016. "Facilitated Ultrasonic Irradiation in the Degradation of Diazinon Insecticide." Sustainable Environment Research 26 (3). Elsevier Ltd: 110-16. doi:10.1016/j.serj.2016.04.003. 
Wang, X., and T. Lim. 2010. "Solvothermal Synthesis of C-N Codoped $\mathrm{TiO}_{2}$ and Photocatalytic Evaluation for Bisphenol A Degradation Using a Visible-Light Irradiated LED Photoreactor." Applied Catalysis B: Environmental 100 (1-2). Elsevier B.V.: 355-64. doi:10.1016/j.apcatb.2010.08.012.

Wellia, D. V., D. Fitria, and S. Safni. 2018. "C-NCodoped $\mathrm{TiO}_{2}$ Synthesis by Using Peroxo Sol Gel Method for Photocatalytic Reduction of $\mathrm{Cr}(\mathrm{VI})$." The Journal of Pure and Applied Chemistry Research 7 (1): 25-31. doi:10.21776/ub.jpacr.2018.007.01.373.

Wu, J., C. Lan, and G. Y. S Chan. 2009. "Organophosphorus Pesticide Ozonation and Formation of Oxon Intermediates." Chemosphere 76 (9). Elsevier Ltd: 130814. doi:10.1016/j.chemosphere.2009.04.060.

Wu, Y., and L. Ju. 2014. "Annealing-Free Synthesis of CN Co-Doped $\mathrm{TiO}_{2}$
Hierarchical Spheres by Using Amine Agents via Microwave-Assisted Solvothermal Method and Their Photocatalytic Activities." Journal of Alloys and Compounds 604. Elsevier B.V.: 16470. doi:10.1016/j.jallcom.2014.03.023.

Xu, Q. C., D. V. Wellia, S. Yan, D. W. Liao, T. M Lim, and T. T. Y Tan. 2011. "Enhanced Photocatalytic Activity of C-N-Codoped $\mathrm{TiO}_{2}$ Films Prepared via an Organic-Free Approach." Journal of Hazardous Materials 188 (1-3). Elsevier B.V.: 17280. doi:10.1016/j.jhazmat.2011.01.088.

Zhou, G. 2013. "Photocatalytic Degradation of Organic Compounds Using Carbon Based Composite Catalysts." Curtin University.

Zilfa, Z., H. Suyani, S. Safni, and N. Jamarun. 2011. "Degradasi Senyawa Permetrin Dengan Menggunakan Zeolit Alam Terpilar $\mathrm{TiO}_{2}$-Anatase Secara Sonolisis." Jurnal Ecolab 5 (1): 35-43. doi:10.20886/jklh.2011.5.1.35-43. 